\title{
Fechados no quarto de espelhos : o perspectivismo ameríndio e o "jogo comum" da antropologia
}

Closed in a mirror room: Amerindian perspectivism and the "common game" of Anthropology

\section{Filipe Verde}

\section{(2) OpenEdition}

\section{Journals}

Edição electrónica

URL: http://journals.openedition.org/aa/1679

DOI: 10.4000/aa.1679

ISSN: 2357-738X

\section{Editora}

Programa de Pós-Graduação em Antropologia Social (UnB)

\section{Edição impressa}

Data de publição: 1 julho 2017

Paginação: 137-169

ISSN: 0102-4302

\section{Refêrencia eletrónica}

Filipe Verde, «Fechados no quarto de espelhos : o perspectivismo ameríndio e o "jogo comum" da antropologia», Anuário Antropológico [Online], v.42 n. 1 | 2017, posto online no dia 08 junho 2018, consultado o 27 abril 2021. URL: http://journals.openedition.org/aa/1679 ; DOI: https://doi.org/ 10.4000/aa. 1679

\section{(c) $(1)(9)$}

Anuário Antropológico is licensed under a Creative Commons Atribuição-Uso Não-Comercial-Proibição de realização de Obras Derivadas 4.0 International. 


\title{
Fechados no quarto de espelhos: o perspectivismo ameríndio e o "jogo comum” da antropologia
}

Filipe Verde

ISCTE-IUL

\begin{abstract}
'Pon my word, Watson, you are coming along wonderfully. You have really done very well indeed. It is true that you have missed everything of importance, but you have hit upon the method.
\end{abstract}

Arthur Conan Doyle

There seems to be a dilemma: either we anachronistically impose enough of our problems and vocabulary on the dead to make them conversational partners, or we confine our interpretive activity to making their falsehoods look less silly by placing them in the context of the benighted times in which they were written.

Richard Rorty

Intellectual impostures always require convoluted jargon, whereas fundamental values can normally be defined in clear and simple language.

Simon Leys

A história é, todos o sabemos, imprevisível, e assim, contra intenções, expectativas e antecipaçóes, desembocamos sempre em circunstâncias inesperadas. É o que acontece quando consideramos o presente da antropologia à luz da história que a ele conduziu. Se atentarmos às expectativas que muitos desenvolveram nos últimos, digamos, 30 ou 40 anos, a antropologia já se devia ter diluído numa pan-etnografia da modernidade e de todos os cruzamentos do local e do global tendo em vista cumprir a sua missão político-relativizadora de trazer à atenção todas as dimensões alter, marginais, subalternas e minoritárias da contemporaneidade. Em vez de aldeias, fluxos; em vez de lugares, não lugares; em vez de instituiçóes, processos instituintes; em vez de identidades, processos de construção e afirmação identitária; em vez de reflexão, militância e por aí fora... Em certo sentido, a história deu razão a quem assim antecipou o caminho que a antropologia havia de tomar, neste tempo em que é já muito remoto o laço (existirá ainda algum?) que une o que Malinowski e Boas faziam entre os trobriandeses e os Kwakiutl, e o que fazem os militantes pan-etnógrafos multissituados e não situados da contemporaneidade. 
No entanto, contra essas expectativas, ainda perduram nos departamentos de antropologia alguns núcleos que mantêm um sólido vínculo ao passado, e em termos que por vezes são eles próprios inesperados. Afinal, nas páginas que se vão escrevendo hoje em antropologia há muitos caçadores-recolectores e sociedades tribais, como há também, apesar do seu tantas vezes proclamado fim, muita teoria, aliás solidamente ligada à história teórica da disciplina e aos seus temas clássicos. Por detrás e indiferente ao carácter festivo das rupturas e reinvenções que se foram sucedendo, esteve sempre um fio condutor, um elemento fundamental de permanência, sem o qual faria hoje muito pouco sentido tomar a antropologia como objecto de reflexão. Contra a dispersão temática e a negação das fronteiras disciplinares, resistente a mil modas e transgressóes que atravessaram, a antropologia, e o que merece por isso ser assim chamado, tem permanecido fiel a um conjunto circunscrito de problemáticas e de estratégias-tipo para lidar com elas.

Parece consensual que o que mais importante se faz hoje no quadro da teoria antropológica foca esse tópico, que constantemente se foi procurando transcender mas foi sempre teimosamente permanecendo, que é o da elucidação de como é possível pensar congruente e fecundamente a relação entre natureza e cultura, o conteúdo de uma e outra noção e o modo como confinam o que é, e como entendemos o que é, ser-se humano. Ingold tem sido aquele que o tem feito de forma mais consequente - e a forma é tanto mais consequente quanto mais revela como seria saudável deixarmos para trás esse vício de pensamento. Mas, na etnologia brasileira, a questão foi elaborada em termos que a recombinaram com os velhos mas entretanto renovados tópicos do totemismo e do animismo, num esforço de transformação significativa dos termos do debate. Falamos evidentemente do lugar onde desembocou a copiosa etnografia das sociedades sul-ameríndias da segunda metade do século XX, o chamado perspectivismo ameríndio, tal como exposto em sucessivos textos pelo seu criador, Viveiros de Castro, e por um vasto número de epígonos.

Muitas das linhas que se seguem tomam por referente o perspectivismo e a sua "reconceitualização radical" do que devemos entender por natureza e cultura - e, por tabela, sobre a própria antropologia - e são um esforço honesto de apresentar as suas ideias-mestras de forma clara. Náo é contudo nem o perspectivismo nem os pormenores da sua cada vez mais complexa elaboração e especulação "metateórica" que nos interessam centralmente. Este não é um texto de um adepto mas de um crítico; mais do que isso, é um texto de alguém a quem a literatura perspectivista entedia profundamente. $\mathrm{O}$ masoquismo que me pode invadir por momentos não é suficiente para integrar na discussão as múltiplas derivaçôes (pós-estruturais, ontológicas) a que, pela mão de Viveiros de Castro e outros, o tema foi e vai sendo 
sujeito. ${ }^{1}$ Fixo com atenção o que basta: o perspectivismo ab ovo, nos primeiros passos da sua formulação pela mão de Viveiros de Castro. Parece-me uma decisão adequada: evito o aborrecimento de uma leitura detalhada das demasiadas páginas que se vão escrevendo sobre o assunto, sem deixar de contemplar o essencial porque é logo aí que está contido o conjunto nuclear de ideias de que nenhuma dessas elaboraçóes posteriores vai abdicar ou deixar de tomar como fundamento.

O perspectivismo nasce com estrépito revolucionário - "radical” é um adjetivo que Viveiros aplica frequentes vezes às suas ideias e empreendimento e, como revolucionário que se pretendeu, quis abrir uma brecha entre o passado e o futuro da antropologia. Para trás ficaria o que Viveiros de Castro chamou de "jogo comum" da disciplina, estéril e esgotado, pela frente um outro jogo, que sem dúvida pareceu prometer a muitos conferir à prática antropológica um novo e mais aprofundado sentido. Naturalmente, o sucesso do empreendimento dependeu disso mesmo, da sua capacidade de captar seguidores e, como é habitual na academia, os seguidores apareceram, e em tal número que depressa o perspectivismo, mais do que se instituir, se tornou uma ortodoxia, e o que passou um dia por incomum ameaça desse modo tornar-se comum - e talvez isso assim seja porque foi sempre afinal isso mesmo, comum.

Com efeito, o perspectivismo é muito menos radical do que os membros do culto acreditam ser. Viveiros de Castro promete ciência revolucionária - tão revolucionária que às vezes se apresenta como anticiência -, mas na verdade faz ciência normal. Para Kuhn, lembremo-lo, as mudanças paradigmáticas são concomitantes de uma mudança de gestalt, uma teoria revolucionária é aquela que, vinda de uma mente crítica, inquieta e inventiva, traz uma outra concepção do domínio dos fenómenos que abarca, e a sua reconstrução da história da ciência (da física, a rigor) sustenta-se no contraste entre esses momentos revolucionários excepcionais e o curso rotineiro e não crítico da "ciência normal" - ou, como poderíamos dizer aqui, "comum". Os membros do culto perspectivista parecem acreditar que são agentes de uma revolução, mas a diferença que existe entre eles e os defensores do couraçado da antropologia que tomaram de assalto é, digamos, do mesmo grau da que separa metodistas de batistas - afinal, apenas diferentes versôes do mesmo credo. Por detrás dos slogans (o mais fascinante para mim é o de que seria a via da "autodeterminação ontológica dos povos do mundo") e de um vocabulário novo e cada vez mais abstrato, o perspectivismo limita-se a reinstituir o que nunca deixou de estar instituído. Longe de instalar uma nova gestalt, ele prolonga velhos pressupostos e rotinas - e é esse, tendo por pretexto o perspectivismo, o tema deste ensaio, o "jogo comum" da antropologia e os equívocos e as limitaçóes que lhe são intrínsecos. 


\section{Você acredita que os pecaris sáo humanos?}

Segundo Viveiros de Castro, o perspectivismo é o resultado de uma síntese teórica construída a partir de uma multiplicidade de trabalhos etnográficos realizados na bacia amazónica por vários antropólogos. O que a seu tempo reclamará a ambição de abarcar o "fundo cultural comum das sociedades ameríndias" - o projeto que já Lévi-Strauss perseguira por via da mitologia tem por ponto de partida uma ideia que alguns desses trabalhos etnográficos de uma forma ou outra encontraram. A ideia em causa, indissociável do complexo xamanístico, é a de que não são apenas os seres humanos que se concebem como tais. Os animais e os espíritos veem-se e concebem-se a si mesmos do mesmo modo e vivem, portanto, em mundos que replicam social e culturalmente o mundo humano. Além disso, ponto significativo, uns e outros são capazes de reconhecer no mundo a presença de animais e espíritos - e é a nós humanos que eles veem como tal. Aí, em contraste simétrico com o nosso sistema de ideias, a natureza não seria una, mas plural (uma pluralidade que se expressaria na diversidade dos corpos), e correspondentemente, a cultura náo seria plural, mas una (dado que sobre essa diversidade dos corpos pairaria uma condiçáo humana e cultural comum). Em vez de culturas múltiplas, uma só cultura; em vez de uma só natureza, múltiplas naturezas. Em corpos diferentes (ou até na ausência de corpos), um mesmo habitante, alguém que se concebe, seja homem, jaguar, árvore, nuvem ou espírito, como um sujeito.

A última grande imagem do pensamento ameríndio fora criada pelo predecessor-fetiche de Viveiros de Castro, Lévi-Strauss. Segundo este, o pensamento ameríndio, representante de uma "ciência do concreto" sustentada numa "lógica das qualidades sensíveis", operaria à maneira de um caleidoscópio, combinando e recombinando os materiais da realidade sensível e produzindo a cada uma dessas combinações uma expressão possível de um padrão último e sintético que seria a impressão digital do "Espírito Humano", definido em termos kantianos, isto é, dos seus princípios estruturais/estruturantes. O caleidoscópio representa as leis universais e constantes da natureza e do "espírito humano" que dela faria parte, as combinaçôes resultantes o modo variável como a cultura, as culturas, a organizam classificatoriamente, sobretudo no quadro da mitologia, o domínio privilegiado de exercício da lógica transformacional aí em ação.

A imagem do pensamento ameríndio que Viveiros de Castro propóe é outra. Ainda um jogo de espelhos, mas onde cada elemento neles reflectido permanece fixo e, ponto significativo, é um sujeito. $O$ pensamento ameríndio é como um quarto de espelhos onde se refletem homens, animais e espíritos (por vezes também plantas e fenómenos naturais, igualmente sujeitos), mas onde todos se 
vêm de um mesmo e simultaneamente diferente modo. Todos humanos para si mesmos, nenhum humano para os outros, cada um deles vê-se e compreendese como os outros o não veem e compreendem. Mas, porque de um jogo de espelhos se trata, as imagens das três perspectivas multiplicam-se até ao infinito, porque se o animal se vê como humano e me vê a mim como animal, sabe entáo que me vejo como humano e a ele como animal - incluam-se ainda os espíritos na equação. O que define então o humano, essa condição que homens, animais e espíritos são para si mesmos? É o facto de todos ocuparem o quarto de espelhos e terem assim uma perspectiva sobre si e os outros e de, por a terem, serem sujeitos, pessoas e, portanto, humanos. Em vez de uma organização lógica, sintática e transformacional das categorias do sensível à maneira naturalista (tal como concebido por Lévi-Strauss), o pensamento ameríndio seria a expressão de uma lógica pronominal semanticamente carregada que desenha uma cosmologia multinatural e monocultural. A visão é sem dúvida inaudita e, para Viveiros de Castro, prenhe de consequências.

Como vimos, Viveiros de Castro alerta-nos frequentemente que o que quer fazer não é "jogo comum" da antropologia, juntar-se meramente ao "jogo de linguagem" e às regras a que a disciplina tem permanecido fiel. E o modo de compreender o jogo que recusa e o que propóe em alternativa é explorar o significado de um episódio por si descrito que envolve um diálogo com uma aluna, que a certo momento de uma conversa lhe teria perguntado: "você acredita que os pecaris são humanos?” A sua resposta foi: "claro que não, eu só acredito em átomos e genes, na teoria da relatividade e na evolução das espécies, na luta de classes e na lógica do capital”. Uma resposta que reconhece, porém, ter sido "perversa e algo mentirosa", porque, na verdade, e embora náo acreditasse que os pecaris eram humanos, "tomava perfeitamente a sério essa ideia”. Viveiros de Castro seguiu assim o preceito relativista da antropologia e de todos os seus predecessores desde pelo menos Malinowski e Boas, que, profissional e metodologicamente, "levaram a sério" tudo o que ouviram dos seus informadores nativos. Mas a aluna voltou à carga: "mas como você pode levá-los a sério se só finge acreditar no que eles dizem?” Viveiros de Castro reconhece que sentiu a pergunta como uma "intimaçáo de hipocrisia" que o obrigou a "refletir", dado estar "convencido que essa questão é absolutamente crucial”, embora "não seja nada fácil respondê-la bem” (2002:132-133). A razão de ser deste ensaio é o reconhecimento de que a questão em causa é de facto crucial, embora por motivos muito diferentes daqueles que Viveiros de Castro e os antropólogos tendem a supor - e também que é muitíssimo fácil responder-lhe bem se recusarmos de facto o "jogo comum" da antropologia. 


\section{Claro que náo acredito, mas...}

O que a pergunta da estudante traz para consideração é uma alternativa que parece ser a origem de todas as "perversōes" e "mentiras" antropológicas. Ou ela é respondida nos termos do pensamento índio, e os pecaris são humanos - ou pelo menos veem-se e compreendem-se como tais, porque aí nada é o que parece e tudo se pode transformar noutra coisa -, ou é respondida nos termos do nosso pensamento de conhecedores de Darwin e Einstein, e nesse caso, evidentemente, os pecaris não são humanos, são, só, pecaris. Para aquele que contemple essa alternativa de forma inocente, dir-se-ia que a questão terminaria aí. Mas, obviamente, não termina, porque estamos perante uma instância, entre tantas, do que tem alimentado as reflexôes e perplexidades que os antropólogos vão tecendo sobre como entender a sua disciplina. Essa ideia e outras semelhantes parecem confrontar a antropologia com um limite que náo deixa de fascinar, e obnubilar, os seus praticantes. Não porque não se possam entender, dado que todos os que são capazes de usar o verbo ser e conheçam o sentido das palavras utilizadas podem perceber o seu significado, mas porque reconhecer o seu significado náo implica que sejamos capazes de acreditar nelas.

É por isso que a primeira resposta de Viveiros de Castro à pergunta da estudante foi "claro que não" - o que é verdade para nós que não somos índios são outras coisas: átomos e genes, a física, a biologia e a escatologia marxista, para retomar os seus próprios exemplos. Não há nada de problemático nisso. A vida oferece-nos abundantes encontros com ideias que consideramos falsas - e todos conhecemos o modo automático e displicente como habitual e, simplesmente, as ignoramos. Porém, num gabinete universitário de antropologia as coisas não se passam assim. Passam-se de um modo muito diferente, dado que o direito a ocupá-los exige uma longa aprendizagem de que é necessário, porque epistemologicamente útil e moralmente virtuoso -, "levar essas coisas a sério".

O resultado prático dessa atitude, que é a marca da identidade profissional do antropólogo e a marca de água da identidade relativista da sua disciplina, foi lapidarmente descrito por Hollis, no quadro dos debates antropológicos sobre a noção de "racionalidade" que, desde os anos 1970 (senão desde sempre), está no centro dos debates sobre a epistemologia da disciplina.

A estratégia geral parece ser: assumir nada, esperar encontrar crenças que se nos afiguram como irracionais; mas fazer sentido delas tornando-as racionais no seu contexto local. Como resultado, as outras culturas emergem globalmente como racionais, desde que a racionalidade seja adequadamente temperada com um modesto elemento de relativismo (Hollis, 1994:232). 
A questão teórica geral da antropologia, nas suas múltiplas versões, sempre foi a de definir a natureza do contexto que tem a propriedade dir-se-ia mágica de converter o irracional em "aparentemente" irracional, em algo que, localmente, é "racional" e "verdadeiro" - embora de uma forma sempre própria e diferente da nossa, daí as aspas. Variando os vocabulários teóricos (funcionalistas, culturalistas, materialistas, estruturalistas, cognitivistas ou interpretativos), trata-se sempre, como o assinala Viveiros de Castro, de explicar e interpretar os mundos outros em termos que lhes são extrínsecos - dado que em nenhum deles se sustêm e (ao que tudo indica) acredita em tais ideias em função do reconhecimento de que elas são funcionais, adaptativas, um output da arquitetura cognitiva do cérebro, ou uma expressão figurada que devolvida à literalidade é, digamos, plausível.

O incómodo é que há crenças que, por mais relativismo que se vá acrescentando ao modo como olhamos para elas, não deixam de permanecer aos nossos olhos como irracionais, ou, dito de outro modo, como não passíveis de poder ser integradas em algo que possamos, no nosso perfeito juízo, considerar como plausível, realista, em suma como verdadeiro, no sentido pragmático em que seja integrável no entendimento do mundo que vai guiando os nossos projetos e açôes. $\mathrm{O}$ antropólogo pode produzir ou guiar a sua investigaçáo por uma teoria da feitiçaria ou da adivinhação, mas isso jamais implica que a feitiçaria e a adivinhação se tornem opçóes válidas para a sua orientação na vida, e se algum deles se torna feiticeiro ou entra a adivinhar o futuro, o caso é meramente psiquiátrico. Como disse Gellner (1995), o antropólogo que perante um júri académico defendesse a ideia de que algo "aparentemente irracional" na comunidade por si estudada na verdade não é irracional nem na aparência, porque "é mesmo assim", seria reprovado. E a primeira e espontânea resposta de Viveiros de Castro à estudante é, inevitável e genuinamente, "não, claro que não."

A prontidão da resposta mostra bem que a dificuldade não está na pergunta que a suscita, mas na atitude não genuína e especificamente antropológica que faz com que, em vez de seguir em frente e em busca de algo que - sim, claro que sim considere ser verdadeiro, relevante e instrutivo, o antropólogo permaneça atolado no dever inconsequente de conferir a ideias desse tipo uma relevância que elas não têm e nunca teráo. Náo podendo reconhecer sem hipocrisia e sem mentir a si mesmos a verdade de ideias desse tipo, os antropólogos jogaram o jogo comum da antropologia, na busca virtuosa e insana de traçar o contexto que permite explicar - e assim justificar - por que alguém crê nelas, e foram assim produzindo construçóes teóricas inevitavelmente holistas, isto é, contextualizadoras na sua orientação e visando a produção de explicaçôes extrínsecas, que lhe permitem cumprir essa finalidade. ${ }^{2}$ Não é preciso assinalar o paternalismo de uma tal 
atitude e o quanto ela pressupóe, como diz Viveiros de Castro, "uma vantagem epistémica sobre o nativo" que leva ao "epistemocídio" do seu pensamento - uma outra coisa manifestamente pouco condizente com o ecumenismo relativista que define a antropologia.

O perspectivismo de Viveiros de Castro resulta da saudável e prometedora decisão de "recusar esse jogo". Como nos diz, e nós subscrevemos, o modus operandi holista e contextualizador como horizonte último das "explicaçôes" antropológicas não ensina nada sobre o que pode importar saber sobre os outros - talvez porque diz demais sobre os antropólogos e os seus vícios de pensamento e de menos sobre esses outros. "Levar a sério uma afirmação como 'os pecaris são humanos', nesse caso, consistiria em mostrar como certos humanos podem levá-la a sério, e mesmo acreditar nela, sem que se mostrem, com isso, irracionais - e, naturalmente, sem que os pecaris se mostrem, por isso, humanos. Salvase o mundo: salvam-se os pecaris, salvam-se os nativos, e salva-se, sobretudo, o antropólogo (Viveiros de Castro, 2002:134). Nem mais - só falta acrescentar que, como argumentaremos, o antropólogo não se salva assim da irrelevância.

Em vez desse jogo assimétrico, Viveiros de Castro quer jogar um outro, que seria simultaneamente "uma experiência de pensamento e um exercício de ficção antropológica" (2002:123). O seu projeto é o de produzir uma "antropologia simétrica" que institui uma continuidade epistémica, e portanto uma relação equivalente e não hierárquica, entre o naturalismo ocidental e o perspectivismo ameríndio - a "etnoepistemologia" que subsume o totemismo e o animismo que Descola (redefinindo essas velhas noçôes que remontam aos tempos evolucionistas) identificou como dois modos de objetivação da natureza. Para instituir essa simetria e continuidade epistémica, haveria primeiro que tudo que tomar as ideias indígenas como conceitos, de modo a "recusar sua explicaçáo em termos da noçáo transcendente de contexto (ecológico, econômico, político etc.), em favor da noçáo imanente de problema, de campo problemático onde as ideias estão implicadas" (2002:123).

Mas a atenção às ideias indígenas como conceitos seria apenas o primeiro passo para o objectivo de atingir o que está aquém destes: "o solo pré-conceitual ou o plano de imanência que tais conceitos pressupóem, os personagens conceituais que eles acionam, e a matéria do real que eles póem” (2002:123). Procura-se assim inquirir "não o modo de pensar indígena mas os objetos desse pensamento, o mundo possível que seus conceitos projetam” (2002:123). Inquirir os modos de pensamento acaba sempre por confundir-se, como vimos, com identificar os princípios da sua determinação à luz de ficções teóricas que Viveiros de Castro quer deixar para trás - "cogniçóes individuais, representaçóes coletivas, atitudes 
proposicionais, crenças cosmológicas, esquemas inconscientes, disposiçóes incorporadas" (2002:123). Inquirir sobre os conceitos indígenas, pelo contrário, garantiria a procurada continuidade epistémica e as possibilidades que ela projeta, por quê? Porque muito conformemente à ideia ameríndia de uma cultura única e de uma natureza plural, os "personagens conceituais" e a "matéria do real" que os conceitos "póem” sendo um "mundo possível” não são uma "visão do mundo", entre outras visões alternativas associadas a diferentes culturas. ${ }^{3}$ Mas, se a "matéria do real" posta pelos conceitos não é uma visão do mundo, o que é então?

Segundo Viveiros de Castro, o seu jogo não é o das "representaçôes", mas o da "construção e expressão de mundos", um jogo, dir-se-ia, infinitamente aberto. Com efeito, colocar em equivalência epistémica os conceitos nativos e antropológicos tem por finalidade explícita colocar uns e outros sob tensão, uma tensão que seria generativa, no sentido em que cada nova "experiência e ficção antropológica" seria produtora de conceitos. Afinal - como o reconhece Viveiros de Castro num raro momento conservador ou pelo menos náo radical -, foi isso que a antropologia sempre fez apesar das premissas equívocas que a guiaram: construir conceitos que, com diferentes graus de abstração e distanciamento dos conceitos indígenas, sempre retiveram no seu interior a assinatura destes - "mana, totem, kula, gumsa/ gumlao ... dom, sacrifício, parentesco, pessoa ... animismo, oposição segmentar, troca restrita, sismogénese" (2002:126).

A antropologia que constrói e expressa mundos tornar-se-ia assim, segundo Viveiros de Castro, "um poderoso instrumento filosófico". Criando conceitos, a disciplina poderia aliás desempenhar o papel de libertar a "nossa filosofia" da sua "dimensão etnocêntrica" ao produzir, como sugeriu Ingold, "uma filosofia com gente dentro", uma "geofilosofia" produtora de uma "filosofia imaginária com selvagens reais" (2002:128). Seja como for e por instrumental que possa ser para uma futura filosofia náo etnocêntrica (um encantador oximoro), a antropologia de Viveiros de Castro náo deixa de reclamar uma filosofia palpitante do presente, procurada em Deleuze, o autor (por vezes com Guattari) que sempre o acompanha nesses passos, que o conduzem por caminhos caracteristicamente vagos e opacos que convidam menos a um confronto com ideias que à entrada no reino das significaçóes misteriosas de um mundo densamente enigmático. E a necessidade de incorporar uma tal filosofia nessa antropologia parece uma vez mais prenderse com o que está em causa na pergunta da estudante e com a dificuldade que o antropólogo tem em responder-lhe sem cair em alternativas inconciliáveis e em alguma espécie de "mentira" e "hipocrisia".

Voltemos portanto aos pecaris, visto que na antropologia não há meio de os evitarmos ou deixarmos de encontrar. Para Viveiros de Castro, o problema 
de ideias como a de que os pecaris são humanos não tem a ver - claro - com qualquer dificuldade de traduçáo. Nós percebemos a ideia, qualquer um que conheça o significado das palavras é capaz de a apreender imediatamente. O problema também náo tem a ver com o facto de ela não poder conduzir a algum consenso (parece aliás impossibilitá-lo), porque não se trata de algo que deva ser concebido como um diálogo entre os modos, sempre assumidos como diferentes (mais do que diferentes, haveria uma "divergência irredutível" entre eles), como índios-perspectivistas e antropólogos-naturalistas pensam e objectivam a cultura e a natureza. Sempre seguindo Viveiros de Castro, não se tratando de um problema de tradução ou de consenso dialógico, o que essa ideia convida a fazer é, como vimos, dissolver a distinção entre o que é "imanente e extrínseco" ao objeto e de "devolver ao nativo a sua condição de Sujeito" - mas de um sujeito que, não sendo um mesmo, é "Outrem" - a figura central do enigma. Outrem "não é ninguém, nem sujeito nem objecto, mas uma estrutura ou relação, a relação absoluta que determina a ocupaçáo das posiçóes relativas do sujeito ou objecto por personagens concretos, bem como a sua alternância: outrem designa a mim para outro $\mathrm{Eu}$ e outro eu para mim" - Outrem é, em suma, "o conceito de ponto de vista", a "expressão de um mundo possível" que "não existe atualmente fora da sua expressão em outrem" mas que é "atualizado por um Eu" (2002:118). E o conceito de ponto de vista na perspectiva deleuziana, o que consagra não é assim o dictum habitual da antropologia da "relatividade do verdadeiro, mas sim da verdade do relativo". O que é a verdade do relativo? Para Viveiros de Castro, "a verdade do relativo é a relação", como "atualização das virtualidades insuspeitas do pensar".

Num tal quadro "filosófico", a pergunta da estudante e a sua possível imputação de hipocrisia não é tanto respondida como pretensamente dissolvida. Em certo e importante sentido, parece ser esse aliás o horizonte último de todo o empreendimento "metateórico" de Viveiros de Castro. Se a verdade está na relação como relação, deixamos de supor que ela esteja de algum dos lados dos termos-conteúdos que a criam e integram, ou tão pouco que haja que escolher entre um ou outro - nem do lado do nativo que crê que os pecaris são humanos, nem do lado do antropólogo que descrê em tal em função de um saber (científico) que é, afinal, "essencialmente arbitrário, para não dizer burro". Assim, o professor pode chegar a fazer compreender a estudante que perguntar sobre as crenças e descrenças de um ou de outro é um "category mistake, equivalente a perguntar se o número dois é alto ou verde”. É que, segundo Viveiros de Castro, “a crença do nativo ou a descrença do antropólogo não têm nada a fazer aqui” (2002:134). $\mathrm{Ou}$, mais precisamente, embora a crença deste último (ou melhor, a sua descrença na crença do nativo) tenha o papel de despertar o seu interesse na ideia de que os 
pecaris são humanos, ela deve, como o "saber burro" que a sustenta, "parar aí". Daí para a frente teríamos apenas a promessa de saber que "não sabemos" e de ver brotar os tão procurados novos conceitos e construçóes do mundo - embora, confesso, leituras e releituras dos textos perspectivistas de Viveiros de Castro e de alguns dos seus epígonos me tenham sempre deixado a sensação de nunca ter encontrado o mirífico "conceito" e o mundo que ele construiria.

O que Viveiros de Castro parece não estar a considerar é que o antropólogo transporta consigo uma outra crença e convicção que, porém, nunca é verdadeiramente trazida a um escrutínio crítico - justamente aquela segundo a qual é preciso "levar a sério" ideias que, genuinamente, não pode levar assim. Será possível, de uma vez por todas, tirar o esqueleto do armário e, então sim, mudar de jogo - isto é, pensar a antropologia, a nossa relaçáo com os outros, a partir de ideias que possamos levar a sério sem hipocrisia ou sem mentirmos a nós mesmos?

\section{A persistência e os equívocos da teoria}

É uma evidência que os seres humanos só procuram explicar o que não compreendem. O que se compreende é por definição aquilo que, por isso mesmo, por ser compreensível, não suscita uma intenção dessa natureza. Assim, foi o facto de o colapso da cosmologia e da física ptolomaica e aristotélica ter tornado o universo e o mundo físico incompreensíveis que aguçou a curiosidade de que havia de nascer a física moderna. E como o universo e os fenómenos físicos, a combustão, a morfologia dos seres vivos ou a distribuição das massas terrestres e dos estratos geológicos. A seu tempo, passo a passo, as ciências que resultaram da vontade de dar compreensão a esses domínios da realidade foram de facto tornando-os compreensíveis em termos em que até então não o eram, e tornaram-no tal na medida em que o foram explicando por recurso a teorias e nunca perdendo de vista a experimentação e a realidade empírica. E assim hoje conhecemos os rudimentos fundamentais da realidade, desde a idade e estrutura do universo aos pormenores da divisão celular e à tectónica das placas - não, a ciência não é de todo um "saber arbitrário e burro".

As ciências sociais nascem como um projeto de percorrer o terreno aberto pelas ciências naturais, mas a sua singularidade por relação a estas manifestase desde logo por não ser aí possível conceber o observador como exterior à realidade que inquire. Os cientistas sociais estudam comunidades de vida, e primeiro que tudo as suas próprias comunidades de vida. Os autores que foram contribuindo para a emergência dessas ciências - desde, digamos, Montesquieu e Condorcet a Marx, Weber e Durkheim - não eram de todo estranhos ao mundo 
que procuravam elucidar, eram muito simplesmente parte dele, o que quer dizer que, portanto, de uma forma ou de outra, concordando ou discordando nas suas visóes, juízos e expectativas, todos eles o compreendiam - aos estatutos sociais, aos valores, à etiqueta, aos mecanismos práticos das relaçóes económicas e de poder, e por aí fora até ao infinito. E no entanto o projeto das ciências sociais depende da ideia de que ele não é compreensível à luz dos recursos comuns da curiosidade e inteligência humana, porque de outra forma, e continuando a seguir o dito plausível de que só procuramos explicar o que não compreendemos, não necessitaríamos de nos envolver na tarefa de produzir teorias para assim, final e supostamente, o enquadrar em termos explicativos.

A razão pela qual os cientistas sociais se envolveram nessa tarefa é uma herança de que contemporaneamente temos boas razóes para ser cépticos, a herança que os fez compreenderem-se como filhos de Descartes e da genealogia da ciência empírica e explicativa e da filosofia fundacional. Assim como os objetos não se movem porque sobre eles esteja a ser exercida uma força, também não seria pela vontade divina ou pela açáo e intençóes dos grandes homens que as sociedades se organizam e transformam. Procurando dar sequência às leis da inércia e da gravitação de Galileu e Newton, os cientistas sociais pretenderam criar os seus equivalentes no plano da história, da sociedade e da cultura. Empreendimento desastroso e que criou equívocos que ainda hoje nos enredam.

A premissa de base desse empreendimento é o que podemos chamar de metáfora da profundidade, segundo a qual é possível e útil distinguir entre um plano superficial de aparências indissociáveis do "senso-comum", da "ideologia", dos "interesses", do "consciente" ou do "poder", e um plano profundo e verdadeiro só acessível a partir do momento em que dispomos de um aparato teórico e metodológico que nos exime do condicionamento a que aqueles, desde sempre e até ao advento de tal aparato, nos condenaram. As leis materialistas da história, as determinaçóes supraindividuais de natureza social e cultural, os mecanismos latentes instintivos ou estruturais do inconsciente, eis o solo fértil que o inquérito guiado pela teoria revela e onde ela deve crescer para, passo a passo, desmistificar contradiçóes, decifrar significaçóes escondidas, trazer à luz, a benefício das multidóes iludidas e reprimidas, a verdade dos fenómenos que tem sob sua alçada. ${ }^{4}$

A seu tempo, porém, e exceção feita aos espíritos mais encarniçadamente objectivistas (que encontraram como último reduto alguma espécie de reducionismo materialista), o cepticismo por relação à mais-valia cognitiva da teoria foi crescendo, à medida que as ideias que historicamente a suportaram se foram esvaziando de sentido e plausibilidade. Foi isso que veio à tona quando 
a erosão do clima moderno e objectivista deu lugar a todas as correntes críticas e cépticas que podemos albergar sob o rótulo genérico de pós-modernismo. No entanto, se o ideal objectivista foi desaparecendo, o horizonte onde cresceu o que deveria ocupar o seu lugar permaneceu o mesmo - como sempre acontece nos movimentos que ao serem meramente opositivos ficam presos à lógica daquilo a que se opóem. É talvez por isso que as correntes críticas da modernidade são tão mais facilmente definíveis pelo que não quiseram ser do que pelo que foram. Não quiseram ser modernas, explicativas, teóricas, fundacionais, quiseram antes ser, e tornaram-se, um conjunto ruidoso de retalhos ("fragmentos" e "polifonias") sem outra unidade que uma atitude adversarial, e diríamos mesmo algo paranoica, de tudo que se suspeita ser parte de uma estrutura de poder ou ideia hegemónica que espectralmente estariam por todo o lado.

Numa palavra, à falta de uma definição coerente que albergue a multiplicidade "experimental" do que supostamente ocupou o lugar do projeto moderno, a "pósmodernidade" e seus avatares não são outra coisa que um negativo desse mesmo projeto. Como num negativo fotográfico em que o que na realidade é preto aparece como branco, inverteram-se os ênfases dados às polaridades modernas: o ideal fundacional e objectivista deu lugar à desconfiança dessas "grandes narrativas" e ao relativismo epistemológico, o ideal da neutralidade axiomática deu lugar ao engajamento político, o da correspondência e da representação ao da expressão criativa dos recessos da subjetividade de cada um. O horizonte de onde brotaram e em que se movem é o mesmo da modernidade - e talvez por isso as suas posturas antiteóricas resultaram, afinal... na produçâo de mais um conjunto de teorias (com inspiração em Gramsci, na teoria crítica, em Baudrillard, Foucault, Deleuze, Derrida e por aí fora) que veio juntar-se ao rol de efemeridades que prolixamente os cientistas sociais foram produzindo. ${ }^{5}$ A dimensão política da sua mensagem atirou-os inevitavelmente para a atitude de suspeita e para a correlata metáfora de profundidade, essas resistentes ideias modernas de que, pontanto, se não emanciparam, e tanto menos se emanciparam quanto estão aí para que, tal como os seus antecessores, por via delas se outorguem visionários num mundo de cegos. Em certo sentido, cometeram assim um epistemocídio da sua própria tradição. Os antropólogos dessa vaga, por seu turno, continuaram a cometer epistemocídios de outras tradiçóes.

Vem esta longa digressão ainda e sempre a propósito do perspectivismo. Porque é bem isso que assumidamente Viveiros de Castro faz e cada vez mais foi fazendo: teoria, teoria e metateoria da pesada, expressa num jargão denso onde nada tem o significado que os seus ingénuos leitores lhe possam atribuir. ${ }^{6} \mathrm{O}$ que essa teoria lhe permite é cavar mais e mais fundo não no pensamento nativo (reduzido a uma 
fantasmagoria de sujeitos humanos, animais e espirituais que não vêm os outros como sujeitos, mas afinal veem porque a reciprocidade "pronominal" implica que todos se saibam tal), mas na própria teoria. Como vimos, o que importa não é saber se os pecaris são humanos ou se alguém acredita ou não acredita nisso, mas o facto de que "essa ideia é o conceito em potência", com pecaris e humanos como suas "variaçóes inseparáveis". (2002:135) O Graal em potência, que o perspectivismo, já não o ameríndio mas o de Viveiros de Castro, busca, e que desemboca não na "auto" mas na heterodeterminação "ontológica" dos povos do mundo. O perspectivismo decreta uma verdade ameríndia insensata como uma verdade sobre o conhecimento e, mais do que sobre o conhecimento, sobre o que é doravante o próprio real - e daí a deriva "ontológica" que não é afinal mais do que uma deriva construtivista. A ambição febril da atitude teórica e presunção de superioridade cognitiva a ela inerente leva-o mesmo à ambição de "construir mundos".

A rigor, não é da ciência e da teoria que Viveiros de Castro e seus epígonos se reclamam - afinal o tal "saber burro" pelo menos no que se refere ao que a antropologia lhe pode pedir -, mas de algo que está para além dela e que se coloca no plano já nem tanto teórico, mas, como vimos, metateórico, já não estrutural, mas "pós-estrutural" e finalmente "ontológico", tomando por inspiração episódica umas poucas e, na minha pobre e medíocre perspectiva, desigualmente (des) interessantes obras antropológicas (Clastres, Wagner, Strathern, Latour) e, de forma mais marcante, o domínio delirante das "díades" deleuzianas de Capitalismo e esquizofrenia. Mas nem por isso o seu empreendimento deixa de buscar a sua vitalidade nas raízes do projeto moderno - duas folhas da mesma árvore. O projeto antropológico de Viveiros de Castro permanece solidamente agarrado ao ideal e à herança modernos, não fosse ele também esse o solo da obra de Lévi-Strauss.

\section{Entre Viena e Cracóvia}

Como filhos da modernidade que somos, tomamos como nossa uma ideia que raramente detém a nossa atenção, mas que tem consequências imensas: a ideia de que a modernidade nasce do estabelecer de uma ruptura e descontinuidade de natureza qualitativa em relação ao passado, à "tradição". Descartes e os seus pares inauguraram a concepçáo que se havia de difundir de que esta é um conjunto de preconceitos que foram a fonte de todos os erros e crenças irracionais de que nós Modernos aprendemos, por sermos tal, a evitar. Um dia a balança da Querela entre os Antigos e os Modernos caiu para o lado destes, que desde então se limitaram a ignorar os erros de perspectiva do passado. Que importam Aristóteles e Ptolomeu para o conhecimento que podemos ter da física e da cosmologia depois de Galileu e Newton? Que importa a alquimia depois de Lavoisier? Que importam os tratados 
naturalistas renascentistas para o conhecimento que podemos ter da vida depois de Buffon, Cuvier e Darwin? A ruptura não foi, claro, absoluta, porque de forma por vezes muito pouco subterrânea houve vozes de raiz e inspiração romântica que sempre foram e vão dando uma resposta crítica à "civilização" científicotecnológica e ao seu entendimento da racionalidade. A vitória dos Modernos deixou os herdeiros dos Antigos - folcloristas, mitólogos, classicistas e orientalistas de várias castas, todos, sabendo-o ou não, irmãos ou filhos de Giambattista Vico -, acantonados e marginais em gabinetes povoados de velhos manuais de filologia e de livros de autores cujo nome já ninguém a não ser eles conhecia. E no entanto, contrariando o movimento de progressivo afastamento entre as ciências e as humanidades, ${ }^{7}$ uma disciplina nasceu a partir de um compromisso singular entre elas, essa que, por isso mesmo, discute a humanidade dos pecaris.

Simultaneamente filha de Cracóvia e de Viena, os termos sugestivos como Gellner (1998) coloca a questão, de um princípio romântico e localista e de um princípio iluminista e universalista, a dupla paternidade da antropologia revelouse ao longo da sua história problemática, dado que não é preciso extremar muito a posição relativista ou a objectivista para que elas se tornem contraditórias, e tão mais indissoluvelmente tal quanto mais as suas posiçôes se vão, como foram, extremando. Em certo e fundamental sentido, a história da antropologia desde os tempos de Boas e Malinowski é a história da tensão entre esses dois princípios cuja natureza contraditória os antropólogos aliás preferiram quase sempre esquecer, adoptando uma epistemologia espontânea e simplista segundo a qual o relativismo seria um método - uma ideia náo muito diferente daquela segundo a qual os pecaris são humanos... Aqueles para quem Viena triunfou continuam a perseguir a busca de explicaçóes extrínsecas dos fenómenos sociais e culturais com sempre renovados vocabulários teóricos. Os adeptos de Cracóvia radicalizaram o relativismo cultural descritivo (resultante da constatação óbvia da diversidade das ideias e crenças humanas) num relativismo normativo (pelo qual a elucidação dessas ideias tem estritamente de permanecer fechada no contexto geral de que fazem parte), e por fim epistemológico (pelo qual a ciência é tornada apenas mais uma visáo do mundo - mais uma "etnociência") e, feito esse caminho, vão agora perseguindo um ideal festivo e irresponsável de interpretação, decifração e desmistificação de sabor sempre político e radical. A rigor, e dada a dupla paternidade da disciplina, os campos estiveram quase sempre misturados, e nenhum deles se conseguiu sobrepor de forma definitiva ao outro porque a antropologia é apenas um dos campos de batalha das "guerras da ciência" ainda em curso. Mas, como em todas as guerras modernas a maior parte das vítimas foram inocentes, neste caso a própria curiosidade antropológica. 
Filhos da modernidade e confiantes que a teoria era fonte de verdade - a rigor a via exclusiva de acesso a esta -, os antropólogos foram de teoria e método na bagagem de encontro a tradiçôes que se tinham desenvolvido totalmente à margem desse acontecimento singular do Ocidente que foi o advento da modernidade tradiçôes (culturas, como lhes haviam de chamar) que, não sendo pré-modernas, eram num sentido significativo o seu correlato. Numa palavra, o grande divisor que a modernidade criou entre o presente crítico e racional e um passado que permanecera fiel da tradição e acrítico dos seus preconceitos deslocou-se com a antropologia do tempo para o espaço, da história para os "selvagens". A partir da perspectiva moderna, que é a do próprio antropólogo, o que há de comum entre o nosso passado e o presente desse outros-nativos é o facto de um e outro serem mundos não modernos - "tradicionais". ${ }^{8}$ A polaridade entre modernidade e tradição definiu assim globalmente a curiosidade antropológica, dando-lhe, digamos assim, um "tom" adequado ao pano de fundo tácito, nunca explicitado e por isso em certo sentido invisível, onde se combinam de forma confusa Viena e Cracóvia, a vontade do conhecimento objectivista e a negação relativista da sua universalidade, o terreno fértil onde cresceu uma disciplina que, assim, ensina aos seus neófitos aquilo que vão encontrar nos lugares da experiência iniciática da etnografia, bem como a estratégia que os deve guiar nesses encontros. Vão, como disse Hollis, encontrar ideias irracionais que devem explicar e, no mesmo passo, justificar por que creem os nativos nelas. Esta alienação postulada é o legado da modernidade para o modo como olhamos para o passado e para o que no presente é culturalmente outro. E nunca faltam nas aldeias nativas ideias dessa natureza crenças e condenaçóes de feiticeiros, cosmologias porventura magnificentes mas objectivamente falsas, imputaçôes causais implausíveis e confusōes categoriais.

O resultado dessa herança Moderna são conversas como a que Viveiros de Castro manteve com a sua estudante e, em termos mais gerais, que toda a discussáo que se pretendeu séria sobre o conhecimento antropológico tenha invariavelmente tomado por referentes etnográficos crenças do mesmo tipo daquela de que os pecaris se compreendem como, e são portanto, humanos - singular característica que a todos devia espantar mas que, estranhamente, não espanta ninguém. Não é difícil imaginar a perplexidade de um classicista a quem uma estudante entrasse no gabinete para perguntar se ele acreditava em oráculos, e de, não acreditando em tal, os "levava a sério"...

Nos seus gabinetes, classicistas, mitólogos e orientalistas - e no que toca à Antiguidade Clássica também filósofos de todas as matizes -, pouco preocupados com o esprit de géométrie, o cepticismo humeano ou o juízo sintético a priori, ou tâo pouco agrilhoados pelos deveres impostos pelo relativismo cultural, preferiram 
não mergulhar angustiadamente no sentido e razão de ser do Oráculo de Delfos, mas sim no que a literatura, a filosofia e a história Clássica e, em geral, o passado têm para ensinar, tiveram sempre para ensinar, sobre questóes que foram desse passado, mas são também e ainda nossas, genuinamente nossas, sobre temas táo diversos como o conhecimento, a ética, a sociedade política ou a arte e o belo. É que o facto de Aristóteles ter identificado classificatoriamente um golfinho com um tubarão - um erro pré-científico - e ter vivido num mundo que confiava nos oráculos e se entregava a sacrifícios de bois e rituais de bacantes não o impediu de nos dizer coisas que têm de estar presentes numa conversa instruída sobre, por exemplo, o que podemos hoje entender por justiça (MacIntyre, 1982; Nussbaum, 1986; Sandel, 2009; Williams, 1981, 1993).

O que a modernidade trouxe consigo foi uma compreensão errada da consciência histórica (e portanto também da consciência etnológica), porque, justamente, acreditou ter emancipado a consciência, por via da intemporalidade e universalidade do conhecimento metodologicamente produzido, da história. Os sonhos da razão assim definida e procurada - uma religião secular afinal -, a própria história, ironicamente, os destruiu, no próprio passo em que dissolveu a ideia de que alguma vez será possível emancipar a consciência - e o conhecimento - de um princípio de finitude e de incompletude, i.e., na expressão de Habermas, dos "a priori transitórios da linguagem e da história". Numa palavra, estamos sempre situados, e a história da ideia de razão e de teoria não pode ser feita independente das suas relaçôes com uma história "externa", como desde Peirce e da epistemologia pós-kuhniana se sabe e vem mostrando. E é talvez por estarmos sempre situados que a modernidade, mau grado o reconhecimento das suas ilusôes, permaneceu por alguma espécie de inércia como o background do modo como continuamos a olhar para o passado e a compreender a natureza da nossa relação com ele.

Irrevogavelmente constituídos pela história, mas negando essa ideia em nome de princípios fundacionais, os modernos foram conduzidos a olhar para o passado, para a "tradição", reproduzindo a solução que Espinosa deu no Tratado teológicopolítico (1677) aos problemas levantados pela constatação de que o conteúdo de algumas passagens dos textos religiosos do judaísmo e do cristianismo não era, à luz de um entendimento racional do que é a realidade, verdadeiro - e assim descobriu na sua própria tradição o análogo da ideia de que os pecaris são humanos. A solução proposta por Espinosa foi o estabelecer de uma distinção que se tornou fundamental para o modo como doravante se olhou para esses textos e, depois, para o passado em geral e, depois ainda, para esses outros não modernos que são os "primitivos": a distinção entre sentido - que ninguém pode 
razoavelmente negar que as palavras dos antepassados têm - e verdade, que não conteriam, dado esta escapar aos seus autores, como pré-modernos que eram. Foi esse o primeiro passo de uma longa caminhada racionalista na qual se procedeu a uma estetização da história, no sentido em que se negou a sua autoridade e em que se deixou de lhe reconhecer um valor cognitivo.

Postulada essa alienação entre presente e passado, a estratégia objectivista que emergiu foi a de que havia que devolver ao passado a inteligibilidade que havia assim perdido, mas de um modo historicamente relativista que o não sacrificasse ao presente, i.e., que náo adulterasse e anulasse o que o separava e distinguia de nós modernos - ou, como se diria na antropologia, que no-lo revelasse "nos seus próprios termos". Assim, o ideal que o historicismo perseguiu foi o de produzir um aparato teórico e metodológico que permitisse revelar os sentidos visados pelos agentes e autores históricos através da reconstrução do contexto que tornava possível - e de certo modo inevitável - que acreditassem no que acreditavam. ${ }^{9}$ A consciência etnológica, como herdeira de Viena e Cracóvia, não é senão um avatar dessa falsa consciência histórica e a antropologia, sem o saber, deixou-se guiar pelas mesmas questôes e estratégias do historicismo - termo que designa aqui o arco que vai de Schleiermacher e Dilthey a Collingwood e Croce. As questôes e a estratégia inaugurada por Espinosa, que procurava descobrir o sentido, que não a verdade, do que é considerado como não moderno. ${ }^{10}$

Não é difícil reconhecer o quanto a curiosidade etnológica seguiu os mesmos passos - como diz Ingold, recitando a máxima das máximas da curiosidade antropológica, "a primeira preocupação do antropólogo não é julgar a verdade de uma proposição mas compreender o que ela significa dado o contexto da sua produção" (2000:14, itálicos nossos). A segunda preocupação é, como vimos, justificá-la tomando como guia uma das teorias disponíveis no mercado, para assim cumprir o mandamento antietnocêntrico de levar a sério o que, na verdade e a sermos autênticos, não podemos considerar como tal.

A tese a que queremos chegar é a seguinte: em certo sentido, a teoria e o método são como uma ponte que pretende ligar os dois lados de uma distância e de uma alienação que eles próprios criam. Como se cada avanço da construção da ponte, e avançado tem ela pela mão de geraçôes de engenheiros, correspondesse a um aumento da distância que ela visa transpor e, assim, a contínua revelação da impossibilidade de alguma vez unir as duas margens - ou melhor, as quatro, porque se pretende ligar também Cracóvia a Viena. O que alimenta esse empreendimento quimérico e o que o vota intrinsecamente ao fracasso é a ideia mesma que o funda, segundo o qual existe um fosso a transpor, uma necessária cegueira compreensiva entre presente e passado e entre nós e o que 
é culturalmente outro - essa ideia sumamente Moderna que se manteve firme mesmo sob os ventos pós-modernos e que se tornou, aliás, tanto mais central na antropologia quanto mais o relativismo descritivo foi dando lugar ao relativismo normativo e ao pressuposto inerente sobre a incomensurabilidade entre as ideias de mundos históricos e culturais diferentes. ${ }^{11}$

Mas os mundos humanos e as ideias que os definem e lhe dão um cunho e um carácter próprio não nos são acessíveis apenas na condição de os inquirirmos a partir de uma perspectiva imanente, como se fossem entidades apenas transparentes a partir do seu próprio interior e opacas para o olhar que permanece fora delas. A história oferece talvez milhóes de desmentidos dessa ideia de que a diferença cultural na ausência da "teoria" e do "método" se constituiu como um obstáculo compreensivo e como invariavelmente conducente a uma incompreensibilidade primordial e, em última análise, ao etnocentrismo. Afinal, árabes e persas traduziram para as suas línguas os textos da antiguidade grega, os mesmos textos que ao longo dos séculos XI e XII foram traduzidos pelos europeus para o latim; os chineses traduziram as Categorias de Aristóteles para chinês no século XVII, um século depois de os europeus terem feito o mesmo ao Corão e às obras de Confúcio e depois aos textos da tradição védica e bramânica - meros episódios de algo que percorreu e permeou a história das sociedades humanas desde sempre. Se é verdade que a diferença cultural é por vezes o lugar do etnocentrismo, também é verdade que é desde sempre o quadro de uma curiosidade ávida - de que a própria antropologia é testemunho - pelo modo diferente como os outros pensam e fazem. E as ideias, desde sempre na história humana, viajaram mesmo mais do que os homens, numa imensa rede de trocas intelectuais (e tecnológicas) que se fez acompanhando as migraçôes, o comércio e os exércitos. O único que crê na opacidade dos mundos culturais é o antropólogo, esse filho da cesura moderna entre modernidade e tradição, pois como não crer nisso se é essa a razão do modo como se entende e ao seu papel no mundo?

Em suma, o esvaziamento da autoridade e valor cognitivo da história é o correlato da assunção moderna do primado epistemológico da teoria e do método. Desse modo, os modernos atiraram-se para a busca de produzir a verdade sobre a história (ou sobre a arte, ou sobre a cultura), no passo em que, orgulhosa e confiantemente alcandorados na teoria, perderam o rasto da verdade $d a$ história, $d a s$ culturas e $d a$ arte. Como se fosse tanto mais imperativo obter ou decretar uma verdade sobre essas coisas quanto mais elas deixaram aprioristicamente de ser reconhecidas como fontes possíveis de educação e de verdade - a ideia que está por detrás de que a compreensão de Homero ou Virgílio exige uma teoria da literatura, ou pior ainda, uma teoria semiótica, a compreensão da história da 
arte uma teoria económica ou das classes, e, no caso vertente, que a fecundidade cognitiva e educacional da diversidade cultural tenha por condição alguma forma de teoria ou metateoria antropológica.

A teoria é uma ponte que liga os dois lados de uma distância que ela própria criou e que abre tanto mais as margens que pretende unir quanto mais enviesa a curiosidade dos seus praticantes para o que vai exigindo a própria intervenção da teoria e do método. Nesse círculo vicioso, não há meio de nos libertarmos de um enviesamento fundamental da curiosidade - e de cada vez que nos interrogamos sobre se os pecaris são humanos o que afirmamos sem o sabermos é o carácter espúrio da curiosidade antropológica quando assim conduzida. E, nunca é demais lembrar, como modo de devolver autenticidade à curiosidade antropológica, a ideia segundo a qual o sentido de um testemunho do passado e de um qualquer mundo-outro supóe mais e outra coisa que a identificação de sentidos das ideias e açóes por via da reconstrução do contexto que as enquadra, porque antes e mais do que isso supóe a partilha de uma compreensão e de um acordo sobre a relevância do assunto assim em discussão. Como diz Gadamer,

to understand [a historical text] does not mean primarily to reason one's way back into the past, but to have a present involvement in what is said. It is not really a relationship between persons, between the reader and the author (who is perhaps quite unknown), but about sharing in what the text shares with us (1961:391).

Reconhecer esta evidência que sempre se prefere ignorar à luz de uma mais ou menos postiça presunçáo relativista, não é abraçar o facilitismo alter dos guerrilheiros da anticiência - aí é que não há mesmo nada com que valha a pena perdermos tempo.Éantes reconhecer que, por muito "simétrica" que a antropologia tenha querido e se tenha proclamado ser, ela nunca o será verdadeiramente enquanto não deixar para trás a herança que recebeu de Viena, i.e., enquanto não deixar de tomar por guia a teoria e por deleite a metateoria e o seu vocabulário táo cada vez mais especializado e "reconceituado", tão cada vez mais narcisicamente fechado sobre si próprio e mais ambicioso e crente na possibilidade de "construir mundos" - não basta o mundo rico e complexo, e existente, que temos?

Mas a antropologia também não será simétrica enquanto não deixar para trás Cracóvia e a sua presunção relativista, à luz da qual os julgamentos de valor e os juízos cognitivos devem terminar onde termina o nosso próprio mundo e onde tudo o que está para além dele tem portanto de ser "levado a sério" - na verdade, nada levado a sério, porque o ato mesmo de o explicar é sintoma de que não o podemos levar assim. Nessa prisão relativista, não é possível dizer naturalmente 
que não, "claro que não" acreditamos numa ideia que encerra uma imputação causal aberrante ou uma confusão categorial, como não há lugar para um crivo cognitivo que distinga o que é espúrio e autêntico na nossa curiosidade, que defina critérios de relevância na relação que mantemos com o que é histórica ou culturalmente distante - na medida em que de facto o respeitemos e deixemos para trás todas as formas de paternalismo que inevitavelmente informam os construtores e fiéis discípulos da teoria. Enquanto acreditarmos que é nossa tarefa "levar a sério" a ideia de que os pecaris são humanos, que aquilo que os nativos nos têm para dizer de mais importante são ideias desse tipo e, por fim, que elas têm o condáo de iluminar e aperfeiçoar essa mesma teoria, não nos libertaremos dos "epistemocídios" que tal crença, contra as suas intençóes professadas, acaba por causar, nem táo pouco da mentira e da hipocrisia que, meritoriamente, Viveiros de Castro quer libertar o empreendimento antropológico sem que, no entanto, e por radical que tenha sido o seu esforço, o tenha conseguido.

Fiel à premissa moderna de que os nativos "não pensam como o antropólogo" (2002:119), que os "conceitos e descriçóes que produzem são muito diferentes dos nossos e portanto descrevem um mundo que é muito diverso" (2002:124), que têm um ponto de vista sobre a realidade que é "completamente heterogéneo" (2002:123) e apresenta uma "divergência irredutível" (2002:138) por relação ao nosso, Viveiros de Castro reitera o pressuposto de uma alienaçáo primordial entre nós modernos e os mundos não modernos e dá a esse falso problema a mesma resposta que a antropologia anda a dar desde há cem anos - a produção de uma elaborada, complexa e muito abstrata teoria e metateoria que, por simétrica que pretenda ser, é mais um lanço da ponte que nós construímos e não leva senão a estender da distância que, assim, sempre nos separa do "nativo relativo". Em nome do "conceito" e de qualquer mundo a assim criar, continuamos a matar o saber nativo, como se o que ele tivesse de importante a dizer-nos fosse a sua crença de que os pecaris se veem como humanos; e, por tabela, também a matar o saber antropológico, como se o que tivesse de importante para fazer fosse mais uma "reconceitualização" da estafada antinomia da natureza e da cultura (à escolha agora, de acordo com a perspectiva, qual é plural e qual é singular).

\section{Outro jogo, que náo o comum}

Seja o que for que os nativos nos ensinem, só nos ensinam - só nos dão na medida em que os tornemos nossos interlocutores, parceiros de uma relação que, evidentemente, não é outra coisa do que um diálogo entre sujeitos - e com eles entre tradiçôes. Não entre "sujeitos" animais-humanos ou humanos-animais perdidos numa relatividade pronominal insanável que cruza as vagas fronteiras 
do que se possa entender por "natureza" e "cultura", mas entre sujeitos que participam desse diálogo a partir das suas perspectivas antropológicas e culturais específicas, como interlocutores de uma dialética sempre inacabada de questôes e respostas que, enquanto existirem, o mantêm vivo - e, hipoteticamente, nos vai educando e edificando. Algo que, mais uma vez, a história humana testemunha e ilustra continuamente.

Deixando para trás a miragem da produção de verdades teóricas que se espremidas se revelam secas e duras como uma noz - e cujo tempo de vida nos círculos académicos é, com sorte, o de uma ou duas geraçóes -, não há como não reconhecer que o horizonte da fecundidade do conhecimento antropológico (como do conhecimento histórico, quando não se perde ele próprio no enlevo pela teoria) é o de uma verdade não metodológica, mas humanística, dialógica e pragmática. Uma verdade que se nos revela como tal enquanto adequada para, cientes da nossa finitude e falibilidade, pensarmos crítica e realisticamente as questóes que, a partir da nossa posição situada, o mundo, e esses outros, nos sugerem. E se não é uma verdade que advém de alguma teoria, não pretende também ser uma verdade sobre eles, mas antes uma verdade deles, no sentido em que é deles que a recebemos, porque é através deles que a chegamos a conhecer.

O que o desenrolar histórico do projeto objectivista e metodológico, por um lado, e o acirrar do relativismo cultural, por outro, determinaram na antropologia, como em geral nas ciências sociais quando se guiaram por eles, foi que se deixasse para trás a mais humana, complexa e necessária das noçôes: a noção de verdade. Uma noção ao mesmo tempo táo inequívoca e tão indefinível - talvez porque, como disse Yeats, "man can embody the truth, but he cannot know it". Procurar os critérios gerais do verdadeiro, ironizava Kant, é como tentar ordenhar um bode sabendo que, no entanto, independentemente da impossibilidade de definir esses critérios, é muitas vezes possível dizer sobre algo que "sim, é verdade".

Sim, é verdade que as experiências estéticas nos movem e transformam o modo como nos compreendemos; sim, é verdade que o carácter é uma virtude; sim, é verdade que a justiça é um ideal humano; sim, é verdade que nenhum ser humano pode dispensar a referência, uma referência contínua, ainda que tantas vezes no background, à própria verdade. Não assumindo a verdade, nesta sua dimensão pragmática, como o horizonte crítico do conhecimento que procurou produzir, a antropologia, como toda a reflexão humanista que pretendeu tornar-se teórica e científica, caiu no que Barzun, a partir da sabedoria dos oitenta anos, chamou de falácia da misplacedsignificance (2000:607), ou seja, num enviesamento sistemático da curiosidade em direção a planos de irrelevância e de inautenticidade (ou, nos termos de Viveiros de Castro, de "mentira" ou "hipocrisia”). É essa falácia que 
leva a conversas como aquelas que narra ter mantido com a estudante, em que esta, ainda não contaminada com a ideologia profissional da disciplina, e por isso ainda com a sabedoria virtuosa do senso comum, na perplexidade sobre as crenças do seu professor, ecoava nas suas perguntas algo que Goethe expressou melhor que ninguém: "uma ação ou evento detêm interesse não porque podem ser explicados mas porque são verdadeiros". Como, de facto, levar a sério aquilo em que se só finge acreditar?

Essa falácia da significância deslocada condicionou demasiadas vezes a natureza dos encontros que os etnógrafos tiveram pelas aldeias do mundo. Certamente tornou a antropologia globalmente menos fecunda e com menos valor prático do que poderia ter tido. Sem dúvida tornou-a demasiado teórica. Porventura em algumas dessas aldeias onde se acredita que os homens são araras, os gémeos pássaros, ou os pecaris humanos, havia ideias, costumes, crenças, especulações, a que valia e vale a pena prestar mais atenção do que a que se prestou. Se libertos do entendimento espúrio de que a sua tarefa é a de oferecer interpretaçóes verdadeiras de falsidades, ou a explicação teórica e metateórica sofisticada de absurdos, os antropólogos estariam também libertos do seu nefasto e tantas vezes irresponsável preconceito justificatório e, quem sabe, teriam de responder por menos "epistemocídios" do que aqueles que acabaram por ser cometidos.

É o erro fundamental de perspectiva que conduziu a esses epistemocídios que a tradição humanística permite contornar. Ela permite-nos considerar a nossa relação com o que é culturalmente outro pelo ângulo da ideia simples e evidente de que só é possível ter uma curiosidade genuina pelo que é outro na medida em que o saibamos também como um mesmo, e portanto como um interlocutor ocasional de uma troca de ideias que se tece em torno de questôes, dilemas, contradiçốes e finalidades que nos são comuns. Uma troca de ideias que se deve suportar, que tem por condição, um mútuo comprometimento com a possível verdade do que se diz e do que se escuta, a verdade que é portanto o crivo crítico que nos permite distinguir entre as situaçóes em que vale ou não vale a pena travar esse diálogo - como é aliás também o crivo crítico das interpretaçóes que através dele tecemos sobre os assuntos e temas em discussão. ${ }^{12}$

É desse diálogo que pode resultar o que Gadamer chama de "fusão de horizontes", a metáfora que descreve o que um dialogo genuíno faculta: a extensão e aprofundamento do campo do visível, do compreensível, do entendimento do que é ser humano e das questôes - éticas, políticas, epistemológicas, religiosas, estéticas - em que essa condição se expressa. Como diz Gadamer, "o reconhecimento de nós mesmos no que nos é estranho e a capacidade de tornarmos esse estranho na nossa casa são o movimento básico do espírito, cujo ser consiste apenas em retornar 
a si a partir do que é outro" (1961:50). Uma frase que descreve o movimento que está por detrás da consciência histórica e da curiosidade humanística, que sempre se alimentaram desse movimento - desse diálogo - que, ao transportarnos para lá do horizonte limitado da nossa situaçáo existencial, nos faz mover, nos educa e nos forma - o que os alemães chamaram de Bildung e conceberam como o desígnio último da educação humanística. Os românticos viram a história, a arte e a viagem como fontes e condição dessas experiências formativas, que a antropologia o seja também, quando e se o conseguir ser, e só o conseguirá quando, de facto, mudar de "jogo".

Ter da antropologia um entendimento humanístico e não teórico e metodológico significa deixar para trás noções como explicação, estrutura, função, sistema, causa, necessidade (e os seus avatares mais modernaços e cada vez mais bizarros, foucaultianos, deleuzianos ou outros), e substituí-las pelas categorias (que permanecem e devem permanecer no background tácito de qualquer diálogo genuíno, digamos que como seu "utensílio" que não requer ser tematizado) de senso comum, juízo e gosto - e num segundo plano, de aplicação e phronesis. São essas dimensóes não metodológicas que sempre nos guiam quando lidamos com as entidades como as que, como antropólogos, inquirimos. Entidades institucionais, ontologicamente subjetivas, i.e., que existem na e pela interpretação, em razão de um consenso intersubjetivo sobre o seu sentido e finalidades. Entidades que, portanto, são sempre elas próprias na medida e na condição em que o sejam sempre diferentemente - e que assim evadem toda a tentativa de pensar o conhecimento que delas podemos ter, ou que elas nos possam facultar, nos termos dualistas e viciados da oposição entre objectivismo e relativismo.

Deixar para trás esse último lastro da modernidade permite-nos compreender algo que, mais uma vez, é da ordem do evidente e só tem de ser dito aos que permanecem fechados em algum quarto de espelhos: que, naturalmente, é possível que haja uma pluralidade de interpretaçôes verdadeiras de algo - de um texto, instituição, obra de arte, forma de vida -, e que isso não é contraditório com o facto óbvio de que ele pode ser mal, e às vezes muito mal, interpretado. Todos nós, como seres humanos e por sermos seres humanos (essa entidade a que Heidegger chamou Dasein e se define por manter uma relação interpretativa consigo própria e que, dessa forma, é os modos como se compreende), somos, quando a nossa curiosidade é genuína e não meramente nocional, compulsivamente movidos pela procura de compreender e interpretar bem - o que necessariamente implica que temos, como não?, a noção que se pode interpretar mal. Mas não vale a pena perguntar ao leitor de um livro ou poema, ou ao espectador de uma peça de teatro, ou ao ouvinte de uma sinfonia, ou ao autor ou leitor de uma etnografia, 
qual o algoritmo ou sistema de regras em função do qual ele chega a um juízo sobre o valor de uma dada interpretação. Isso pertence ao je ne sais quoi que sempre acompanha o juízo do gosto ou, se se quiser, o juízo estético que, como mostrou Gadamer, é o modelo mesmo do conhecimento humanístico. ${ }^{13}$

Ter da antropologia um entendimento humanístico e não teórico e metodológico significa também deixar para trás o sacrossanto princípio de que "a primeira preocupação do antropólogo náo é julgar a verdade de uma proposição, mas compreender o que ela significa dado o contexto em que é produzida" e de o trocar pelo seu simétrico: não é apenas possível como também desejável tornar a primeira preocupação do antropólogo julgar a verdade (ou não verdade) da proposição, independentemente do contexto em que é produzida e em função de julgamentos e critérios que são irrevogavelmente - como poderia ser de outra maneira? -, os seus e os do seu mundo. Uma antropologia assim guiada é uma antropologia que pode ser descrita e entendida do modo como Nagel, a partir do pragmatismo, descreve a ética:

não há axiomas, apenas questôes que procuram ser o mais amplamente compreensíveis possível, e respostas de crescente sofisticação que atraem um campo amplo de acordo e desacordo, seguidas de novas questóes. A finalidade é construir gradualmente uma perspectiva que todas as pessoas razoáveis possam ser convidadas a partilhar (1995:206).

A antropologia seria, assim, um diálogo com a diferença cultural sempre democraticamente aberto ao futuro e aos modos forçosamente diferentes como este o for travando, na certeza de que, como vimos, é possível interpretar de forma multiplamente verdadeira sem que isso implique que não haja e não seja possível identificar o que são más interpretaçóes - uma ideia que os herdeiros e partidários mais ou menos apóstatas da polaridade moderna entre objectivismo e relativismo manifestamente não conseguem entender. Não explicação em termos extrínsecos, mas diálogo e interpretação; não contextualização explicativa do falso, mas integração, assimilação e aplicação do verdadeiro como meio de promover uma fusão de horizontes; não litero-filosofia-confuso-radical, mas fenomenologia existencial séria e doses reforçadas de pragmatismo; não abstraçôes teóricas e metateóricas, mas inocência e cultura, muita cultura humanística - porque é esta, isto é, o convívio com a história, com a arte e com o que é culturalmente outro que vence o paroquialismo e afia as faculdades da interpretação. 


\section{Esqueça os pecaris}

Imaginando que uma estudante entrava no meu gabinete para me dizer que estava a ler os textos perspectivistas e perguntar se eu, como antropólogo, acredito que os pecaris são humanos, o que lhe responderia? Que esses textos, na sua voluntária opacidade e radicalismo, sáo incitadores para pensar as questóes que a antropologia há muito, com prejuízo próprio, evita confrontar, mas que não apontam caminhos para sair do quarto de espelhos onde se fecharam. Por vezes certeiros no diagnóstico, falham dramaticamente na terapêutica proposta - não é preciso sangrar mais o doente com as agulhas da teoria ou sequer da metateoria porque se calhar está quase cadáver por causa de todas as sangrias feitas.

Dir-lhe-ia também que perguntar sobre as crenças e descrenças dos nativos e dos antropólogos não é um category mistake porque essas crenças e descrenças são tudo o que importa e, de certa forma, são o que faz a antropologia, no sentido em que são o que lhe dá existência e em que são (algumas, só algumas delas) o possível solo sólido de um crivo crítico de que nenhuma proclamação de conhecimento pode deixar de colocar. Em última análise, são as crenças do antropólogo que determinam as suas escolhas sobre o que interrogar e como o interrogar. Algumas dessas crenças levam-no a interrogar ideias como a que os pecaris são humanos e a envolver-se num desígnio teórico que ganha aparência de sofisticação e poder intimidatório pela adopção de um jargão abstrato onde as ideias perdem clareza sem que algo se ganhe no plano da relevância. Outras crenças podem levá-lo a interrogar aquilo que nesses mundos com quem escolhe dialogar se lhe apresenta, como dissemos, como algo que considere como plausível, realista, instrutivo, em suma como verdadeiro, no sentido pragmático em que seja integrável no entendimento do mundo que vai guiando os seus projetos e ações - e que desta forma assume uma autoridade efetiva sobre si, afinal, a condição única e elementar da simetria que a antropologia tantas vezes procura e proclama. É esta última forma de curiosidade que permite, porque aliás tem por condição, colocar em risco e sob desafio as certezas que o nosso mundo paroquial nos convida a ter sobre a condição humana e aquilo que a faz e em que se traduz - em hábitos, preferências, gostos, crenças, valores, mitos, rituais, arte, cosmologias.

Temos pouco a aprender com as cosmologias que nos dizem que a Terra tem a forma de um disco, afinal também não há nada de realista a aprender com a cosmologia ptolomaica ou até a kepleriana; teremos também pouco a aprender - porque sobre isso já aprendemos demasiado e tudo o pouco que há para saber sobre feitiçaria, xamanismo, oráculos e adivinhação, esses temas que apaixonam e tantas vezes esgotam e condenam à irrelevância a curiosidade antropológica; mas temos muito a aprender nesses outros domínios que são a moral e a ética, a 
especulação metafísica e ontológica e, com um lugar estratégico e aglutinador, a arte. Não para afirmar algo sobre esses assuntos ou sobre o que dele pensam os nossos interlocutores por via de algum jargão que apenas os iniciados podem entender, mas simplesmente para podermos ser educados por eles, permanecendo o que somos de uma forma que não éramos, porque em diálogo com eles apreendemos e chegamos a conhecer algo que de outra maneira não chegaríamos sequer a conceber. Novamente a Bildung, essa veneranda finalidade da educação humanística que se fecha de cada vez que um antropólogo se tranca no quarto de espelhos e começa a jogar o jogo comum da antropologia.

Mas, antes de lhe pedir para não me importunar mais com questóes disparatadas, far-lhe-ia uma sugestão: leia também $O$ mármore e a murta, que mostra de forma admirável como, apesar dos seus equívocos, a antropologia, nos seus melhores momentos descritivos e interpretativos, e tantas vezes nas entrelinhas de textos de que já nem lemos ou consideramos as partes teóricas, nunca deixou de fazer: mostrar e dar a compreender mundos e, no ato de o fazer, de transformar a forma como os vemos e a nós próprios. $\mathrm{E}$ a antropologia - ou talvez mais a rigor a etnografia - fê-lo tanto melhor e de forma tanto mais fecunda e rica quanto maior essa coisa radicalmente não metodológica que é o talento - a cultura e sensibilidade humanística, o gosto, o tacto, o bom senso e a imaginação literária - do seu autor-etnógrafo. Infelizmente, Viveiros de Castro a esses talentos deixou-os para trás, talvez por nunca ter chegado a perceber que o obstáculo a ser vencido não é o da diferença, mas o da miragem moderna e metodológica que torna essa diferença obstáculo e pretexto de metateoria.

E quando a aluna estivesse a sair do gabinete, talvez lhe dissesse ainda: se quer ser uma boa antropóloga, leia literatura, pode começar pelo começo mesmo, por Homero, e leia historiadores e classicistas e orientalistas, e também filosofia e história de arte. $\mathrm{Na}$ antropologia, leia etnografias, há-as magníficas, e são janelas para mundos que assim poderá descobrir como fascinantes e, quem sabe, de alguma forma, como seus. Se isso acontecer, e acontecerá tão mais facilmente e instrutivamente quanto maior for a sua educação humanística, eles ensinar-lhe-ão algo que se tornará parte de si, algo que reconhece como verdadeiro. Poderá então convidar os outros a partilhar o que encontrou, sem que se outorgue da capacidade de produzir uma palavra ou interpretação final - isso, naturalmente, fica a cargo da história, que, apesar dos sonhos da modernidade, permanece, saudavelmente, aberta e sempre capaz de desfazer ortodoxias.

E, por favor, dir-lhe-ia por último, esqueça os pecaris, porque perguntar por eles é ficar preso do estéril "jogo comum” da antropologia. Para evitar a suspeição de hipocrisia, há que ser genuíno e autêntico. O primeiro passo para isso é não pôr os outros a responder a questóes ou a dizer verdades que náo temos - nem eles. 
Recebido em 30/1/2017

Aprovado em 22/5/2017

Filipe Verde é autor de O homem livre: mito, moral e carácter numa sociedade amerindia (Angelus Novus 2008); Explicação e hermenêutica (Angelus Novus, 2010); Exploradores africanos e reis portugueses: viagens ao coraçâo de África no século XIX (em coautoria com Frederico Rosa. Esfera dos Livros, 2013).

\section{Notas}

1. Os mais significativos e equilibrados comentários e apreciaçôes críticas sobre o perspectivismo parecem-me ser Turner (2009), Calavia Saéz (2012), Halbmayer (2012), Ramos (2012) e Rival (2012).

2. Como todo exercício de contextualização, o esforço supóe a referência a um todo, genericamente concebido como uma "sociedade" ou "cultura", que foi ao longo da história da disciplina analogicamente compreendida como um organismo (funcionalismo), personalidade (culturalismo norte-americano), sistema semiótico ou cognitivo (estruturalismo e suas derivaçóes não semióticas e cognitivistas), ou como um texto (a chamada antropologia interpretativa ou pós-moderna).

3. Assim, o colocar em equivalência epistémica o perspectivismo (deles) e o naturalismo (nosso) implica, a seguirmos Viveiros de Castro, conferir afinal um privilégio epistemológico ao primeiro - com efeito, apenas à luz do "monoculturalismo" ameríndio é possível defender a ideia de que não há visōes (plurais) do mundo - dado que aí, lembremo-nos, há várias naturezas e apenas uma cultura.

4. Boudon expressou a ideia de forma crua: a teoria (subsumida como "o freudismo, o culturalismo ou o marxismo") teria "erigido o profissional das ciências humanas em visionário num mundo de cegos" (2009:42).

5. Como disse Benedict Anderson (2016), "the 35 years I spent as a professor of government at Cornell taught me [...] interesting lessons about US academia. The first was that theory, mirroring the style of late capitalism, has obsolescence built into it, in the manner of high-end commodities. In year $\mathrm{X}$ students had to read and more or less revere Theory $\mathrm{Y}$, while sharpening their teeth on passé Theory W. Not too many years later, they were told to sharpen their teeth on passé Theory Y, admire Theory Z, and forget about Theory W.

6. Pela mão de Viveiros de Castro, que parece encontrar em cada simetria e antítese um sinal de iluminação, nada tem o sentido que habitualmente lhe damos. Desde logo a antropologia que teria por objecto a "variaçấo das relaçóes sociais" de uma perspectiva 
que inquire "todos os fenómenos possíveis enquanto relações sociais: todas as relaçóes como sociais", mas que "apenas tem uma vaga ideia do que seja uma relação" (2002:122); cultura, por seu turno, seria “o nome que se dá à variação relacional” (2002:120); "natureza o conjunto das transformaçóes requeridas para se descrever as variaçóes entre as diferentes configurações relacionais conhecidas" (2002:121); corpo "não é sinónimo de fisiologia distintiva ou de morfologia fixa mas um conjunto de afecçóes ou modos de ser que constituem um habitus" (1996:128); "experiência de pensamento não tem o sentido usual de entrada imaginária na experiência pelo (próprio) pensamento, mas o de entrada no (outro) pensamento pela experiência real: não se trata de imaginar uma experiência mas de experimentar uma imaginação" (2002:123).

7. Ver o ensaio clássico de Berlin (1974).

8. Ingold notou-o bem, mostrando ainda o modo de articulação da polaridade entre tradição e modernidade com a de natureza-animalidade e cultura-humanidade: "in short, just as humanity - in this discourse - marks the triumph of reason over animal instinct, so does modernity mark its triumph over learned tradition. The two arguments are of course related, the link between them being the old evolutionary premise that the modern West represents the culmination of the development of intellectual potentials common to the species. If humans are distinguished by the capacity to reason, it is in the West that reason has taken the upper hand in the direction of human affairs. We would be advised to treat both these arguments with equal caution. In particular, we should guard against the temptation to insert a temporal distance between ourselves and others [...]. Anthropological fieldwork is not, as many of our predecessors believed, a form of time travel" (1993:216-217).

9. Isto apesar de a história, como disciplina, ter sempre mantido uma marcada reserva e distância da teoria. Como diz Judt, "a História é uma disciplina particularmente impermeável a grandes especulações teóricas: quanto mais a teoria se intromete, mais a história retrocede" (2005:460). Trata-se de um contraste fundamental com a antropologia, onde a sempre intrometida teoria fez retroceder o nativo para algum e menorizado plano de irrelevância.

10. A crítica do historicismo e da hermenêutica romântica, que foram elementos centrais dessa estetização da história, fez-se no quadro da tradição fenomenológica pela mão de Heidegger e Gadamer, que nesse passo, e sempre por referência a Hegel, mostraram como ela é artificial e empobrecedora da relação que podemos manter com o passado (ou com o que é culturalmente outro, no caso vertente da antropologia): "we think we understand when we see the past from a historical standpoint - i.e., transpose ourselves into the historical situation and try to reconstruct the historical horizon. In fact, however, we have given up the claim to find in the past any truth that is valid and intelligible for ourselves. Acknowledging the otherness of the other in this way, making him the object of objective knowledge, involves the fundamental suspension of his claim to truth" (Gadamer, 1961:303-304). Ou ainda: "Hegel was essentially right: 
the only way to understand a historical expression truly is by leaving its truth claim intact, not by reconstructing its past, re-placing it in its original context, in the manner of Schleiermacher and Dilthey. It can be understood only if it is understood not only as an expression of life but also as an expression of truth; and to do so it must also be integrated with one's own thought, with the present and the future" (Weinsheimer, 1985:151).

11. Essa incomensurabilidade que a antropologia teoricamente guiada tem sempre por horizonte é simplesmente incoerente, e o seu único fundamento é a radicalidade e artificialidade das cesuras modernas: "Radical incommensurability and radical untranslatability are incoherent notions, for in order to be able to identify a form of thought, a language — and we may add: a culture—as the complex meaningful human systems of action and signification that they are, we must be in a position at least of recognizing that concepts, words, rituals, and symbols in these other systems do have a meaning and reference which we can specify, select, and describe in a manner intelligible to us. This implies that there cannot be radical incommensurability and untranslatability: if radical incommensurability were the case, we would not even be able to identify certain units of thought in other cultures as being concepts [...]. If radical untranslatability were true we could not even recognize the other set of utterances as part of a language, that is, a practice that is more or less rule-governed and shared in fairly predictable ways by a certain group of humans. Likewise, if cultures were so radically divergent, we would not be in a position to isolate complex human activities with their myths, rituals, and symbols as meaningful and intelligible wholes and describe these as a marriage ceremony, a feast, or a prayer" (Benhabib, 1999:48).

12. Scruton, a propósito da história da filosofia, afirma algo que tem um valor geral, pois expressa aquela que é a condição última da pertinência do diálogo com o que é histórica ou culturalmente outro: "a fim de participar da história da filosofia, uma ideia deve possuir uma significância filosófica intrínseca, capaz de despertar o espírito de pesquisa de um contemporâneo e afigurar-se como algo que poderia ser sustentável e até mesmo verdadeiro" (Scruton, 1981:18).

13. Como diz Weinsheimer, "there can be no determinate criterion of interpretation. Yet it also the case that every interpretation strives to be true. Many succeed, many fail. But how is it possible to make or recognize a true interpretation when the criterion of truth is not and cannot be given? Decision on the basis of a non-given rule is the function of taste, judgment, and common sense as Gadamer has explicated them. They operate precisely where no determinate rule of operation can be adduced, where procedures cannot be programmed, and where common sense is required to make judgments that cannot be decided by reasons alone. Whether an interpretation is true is a matter of taste. If this seems to denigrate truth, that is only because we have denigrated taste as a cognitive capacity able to arrive at the truth. It is only because we have thought truth is exclusively something that has been or can be proven. Since Gödel and Gadamer, that conception is no longer tenable" (1985:112). 


\section{Referências}

ANDERSON, Benedict. 2016. "Frameworks of comparison". London Review of Books, 21 Jan: $15-18$.

BARZUN, Jacques. 2000. From dawn to decadence - 500 years of cultural history - 1500 to the present. New York: HarperCollins.

BENHABIB, Seyla. 1999. “'Nous' et 'les autres': the politics of complex cultural dialogue in a global civilization". In: Christian Joppke \& Steven Lukes (eds.). Multicultural questions. Oxford: Oxford University Press.

BERLIN, Isaiah. 1974. "The divorce between the sciences and the humanities". In: . Against the current-essays in the history of ideas. Princeton, Princeton University

Press, 1979. 80-110

BOUDON, Raymond. 2009. O relativismo. Lisboa: Gradiva.

CALAVIA SAÉZ, Oscar. 2012. "Do perspectivismo ameríndio e o índio real”. Campos, 13(2):7-23.

GADAMER, Hans-Georg. 1961. Truth and method. London: Sheed \& Ward.

GELLNER, Ernest. 1995. Anthropology and politics - revolutions in the sacred grove. Oxford: Blackwell.

GELLNER, Ernest. 1998. Linguagem e Solidão - uma interpretação do pensamento de Wittgenstein e Malinowski. Lisboa: Ediçóes 70, 2001.

HALBMAYER, Ernst. 2012. "Debating animism, perspectivism and the construction of ontologies". Indiana, 29:9-23.

HOLLIS, Martin. 1994. The philosophy of social science - an introduction. Cambridge: Cambridge University Press.

INGOLD, Tim. 1993. "The art of translation in a continuous world”. In: Gísli Pálsson. Beyond boundaries - understanding, translation and anthropological discourse. Oxford: Berg, 210-230.

INGOLD, Tim. 2000. The perception of environment-essays on livelihood, dwelling and skill. London: Routledge.

JUDT, Tony. 2005. Pós-guerra - história da Europa desde 1945. Lisboa: Edições 70.

MacINTYRE, Alasdair. 1982. After virtue: a study in moral theory. Notre Dame: University of Notre Dame Press. 
NAGEL, Thomas. 1995. Other minds - critical essays, 1969-1994. Oxford: Oxford University Press.

NUSSBAUM, Martha. 1986. The fragility of goodness - luck and ethics in Greek tragedy and philosophy. Cambridge: Cambridge University Press.

RAMOS, Alcida Rita. 2012. "The politics of perspectivism". Annual Review of Anthropology, 41:481-494.

RIVAL, Laura. 2012. "The materiality of life: revisiting the anthropology of nature in Amazonia”. In: Graham Harvey. The handbook of contemporary animism. Durham: Acumen. 92-100.

SANDEL, Michael. 2009. Justice: what's the right thing to do? New York: Farrar, Straus and Giroux.

SCRUTON, Roger. 1995 A Short History of Modern Philosophy. London, Routledge.

TURNER, Terence. 2009. "The crisis of late structuralism: perspectivism and animism: rethinking culture, nature, spirit, and bodiliness". Tipiti, 7(1):3-40.

VIVEIROS DE CASTRO, Eduardo. 1996. "Os pronomes cosmológicos e o perspectivismo ameríndio". Mana, 2(2):115-144. . 2002a. "O nativo relativo". Mana, 8(1):113-148.

. 2002b. A inconstância da alma selvagem e outros ensaios de antropologia. São

Paulo: Cosac Naify.

WEINSHEIMER, Joel. 1985. Gadamer's hermeneutics: a reading of truth and method. New Haven: Yale University Press.

WILLIAMS, Bernard. 1981. Moral luck: philosophical papers 1973-1980. Cambridge: Cambridge University Press. . 1993. Shame and necessity. Berkeley: University of California Press. 


\section{Resumo}

Este artigo estabelece um diálogo crítico com a corrente teórica que hoje domina os estudos etnológicos, o perspectivismo. Situando-o como uma manifestação tardia do projeto moderno, é posta em causa uma ideia que a antropologia herdou deste e que o perspectivismo toma também como sua: a assunçáo de uma descontinuidade, quando não mesmo irredutibilidade fundamental, entre modernidade e tradição. Contra essa assunção que póe em causa as intençôes de uma relação simétrica entre nativo e etnólogo -, propóe-se uma redefinição humanística da disciplina que toma por guia a ideia segundo a qual os planos relevantes da reflexão etnológica são aqueles onde é possível identificar uma comensurabilidade entre os planos da verdade de diferentes culturas. Palavras-chave: perspectivismo,
teoria antropológica, historicismo, interpretação, verdade.

\section{Abstract}

This article establishes a critical dialogue with perspectivism, the theoretical current which now dominates ethnological studies. Placing it as a late manifestation of the modern project, the idea that anthropology inherited from this project and that perspectivism incorporates is called into question: the assumption of a discontinuity, when not even irreducibility, between modernity and tradition. Against this assumption - which undermines the intentions of a symmetrical relationship between native and ethnologist - , this article proposes a humanistic redefinition of the discipline according to which the relevant grounds of ethnological reflection are those where it is possible to identify a commensurability between the domains of truth of different cultures.

Keywords:

perspectivism, anthropological theory, historicism, interpretation, truth. 